\title{
ON THE ISSUE ABOUT THE MOMENT OF INCURRENCE OF RIGHT OF CASSATION APPEAL ON CIVIL CASES IN REPUBLIC OF BULGARIA
}

\author{
Atanas IVANOV \\ "Neofit Rilski” South-Western University, Blagoevgrad, Bulgaria \\ nasko_nbu@abv.bg
}

\begin{abstract}
The right of the party concerned to a cassation appeal is result of specific inspection performed by the Supreme Court of Cassation where examined is the presence of conditions, foreseen in art. 280, par. 1 of Civil-Procedure Code. The right of cassation, however, shall incur from the presence of appellate judgment [1], and not from the specific inspection of Supreme Court of Cassation. The cassation appeal is submitted when the resolution is void, impermissible or inaccurate. This is why the right of cassation appeal is presented and guaranteed by the law opportunity of an individual to oblige Supreme Court of Cassation to rule on the first stage of cassation proceeding - the proceeding on allowing the cassation appeal estimating the statutory criteria in art. 280 of Civil-Procedure Code.
\end{abstract}

\section{Keywords: term, cassation, appeal, grounds, right, permissibility, civil litigation}

\section{Introduction}

The order established in the new CivilProcedure Code [3] for permitting cassation appeal in the presence of the foreseen in art. 280 of Civil-Procedure Code grounds for permitting cassation appeal, is disputable in the Bulgarian procedural law. According to the provisions of art. 280, par. 1 of CivilProcedure Code, liable to cassation appeal are the resolutions of the appellate courts where the court has ruled on material legal or procedural legal issue which is: 1 . decided in contradiction to the practice of Supreme Court of Cassation; 2. contradictory settled by courts; 3 . of significance for the right application of law as well as for the development of the law. The common thing between stated criteria for permissibility of cassation appeal is ruling of the appellate court on legal issue of material and procedural law which issue is a precondition for the permissibility of the cassation appeal, discussed in the appealed appellate resolution. The ruling on the grounds for permitting the cassation appeal (art. 280 of Civil-Procedure Code) does not combine with the common grounds for soundness of the cassation appeal (art. 281 of Civil-Procedure Code) which condition the unlawfulness of the appellate judgment.

\section{Speciality of the Cassion Appeal}

Characteristic peculiarity for the soestablished cassation appeal as a faculty one is that necessary is execution of supplementary requirements with review of performing selection of appeals which the Supreme Court of Cassation will allow to be reviewed in essence. Those conditions are supplementary to the common conditions for permissibility of the petition - the submission of petition within term, appellate of the judgment, presence of legal interest and legitimation of the party, observing the mandatory requisites of the cassation appeal and enclosures thereof. As oppose to the cassation grounds expressing the necessity 
of defense of the party against unlawful deeds through practicing cassation control which in the essence is the judicial activity of Supreme Court of Cassation, the "criteria of art. 280, par. 1 of Civil Procedure Code state a non-judicial function characteristic to only this court to unify the court practice in execution of its constitutional obligation to ensure accurate and unified interpretation and application of the law by the courts" [2]. This is related to the characteristics of the cassation instance as the court of the right not the facts of the dispute and with the stated function to unify the justice on the principal issues of material and procedural law as in case of inaccurate or contradictory practice imposed is issue of interpretative judgment by the Supreme Court of Cassation (art. 124, par. 1 Judiciary Act). In the current system of defense before the third instance - the cassation, not sufficient is only submission of cassation appeal, needed is also an estimate by the Supreme Court of Cassation regarding the permissibility of the cassation appeal - whether to allow the cassation instance to inspect the deed of the appellate court in the presence of the grounds, established in art. 280, par. 1 of Civil-Procedure Code. If the Supreme Court of Cassation establishes that the ruling of the appellate court on the legal issue - material or procedural, preconditions the statutory solving of the specific dispute for analogue cases due to the principal character of the legal issue, significant for the law application, then the presence of positive establishment preconditions an estimate whether the solving of this legal matter in the appellate court is in contradiction with the criteria, stated in art. 280, par. 1 of CivilProcedure Code. This estimate of the Supreme Court of Cassation for permissibility of cassation appeal is not liable to control due to lack of procedural possibility for this. The legislator motivates the restriction of the possibility for cassation appeal with the fact that it may not be placed as purpose of the reform of the civil litigation for in any case it would cause a conflict with the function of the Supreme Court of Cassation the court to secure equal application of the law and development of right as the new regulations of cassation appeal shall be subordinate to the requirement to ensure better possibility for court to secure the equal application of law and development of right due to which the restriction of the cassation appeal opportunity is a way to meet such requirement, but not objective.

Ensuring the uniform application of law and development of right as a function of Supreme Court of Cassation which function is non-judicial, may not and shall not be achieved through restricting the judicial function expressing in performing control of lawfulness of the appellate deeds. First of all present are other ways and means to achieve this function personnel and material assurance for Supreme Court of Cassation, more missing is primate of the non-judicial function of Supreme Court of Cassation expressed in uniform application of law and development of right, over the judicial function of the latter, being performing control over the lawfulness of the appellate deeds. These functions are interrelated, missing is collision between then for they are completing each other - the judicial function preconditions the nonjudicial function. The cassation instance shall not be motivated by the public interest only, namely implementing the rule of uniform application of law and development of right, and shall be motivated by the interest of those suing each other, to whom granted is another legal way to remedy the mistake in the appellate court deeds, remedy of lack of justice in the deeds for the first instance and the appellate court may have reached to unlawfulness preconditioned by the imperfection of justice, performed by one person and initiated by another one. No matter how well-prepared for their activity 
is the judges, no matter how conscientiously and carefully they relate to their obligations, in any case they cannot be fully secured from omissions and mistakes which preconditions the need of third instance. Not only the inaccurate understanding of law or occasional oversight when clarifying factual circumstances on the case but also the subjective attitude, sympathies and antipathies of the judge, as well as the impact of the views and local prejudice in the region may become a reason for ruling wrongly. On the other hand, reason for illegal and unjustified deeds may be the omission in the professional training and insufficient practical experience of the judge; the carelessness and negligence in the work which oversight is sometimes precondition by the overloading of the courts with a large number of cases.

\section{Content of the Cassion Function}

The possibility for inspection of judgments by third instance aims namely to protect the parties on the case and other stakeholders from the mistakes of the judge. When the cassation court establishes mistake and in case it finds other omissions having caused the unlawful settlement of the case, the adopted deed needs certain editing with the purpose of guaranteeing the accurate review and settlement of the case. Led by only concerns that the new regulations of the cassation appeal shall be subordinate to the requirement to ensure better possibility of Supreme Court of Cessation to secure the uniform application of law and development of law due to which has accepted that through restriction of the possibility for cassation appeal this is way and not an aim to meet this requirement the function of Supreme Court of Cassation to secure the uniform application of law and development of right. The legislator, accepting art. 280 of Civil-Procedure Code has neglected the interest of those suing each other before the public interest, assigning to Supreme
Court of Cassation the right to estimate the existence of cassation appeal when present are common, abstract and unclear grounds (criteria) by the legislator on the grounds of which to make the estimate. Reporting the established contents of the cassation function by the Constitution Court has adopted in resolution No 9/24.10.2002 as per constitutional case No $15 / 2002$ and resolution No 6/08.05.2003 as per constitutional case No 23/2002 as well as resolution No 4/16.06.2009 as per constitutional case No 4/2009 that the contents of the cassation function is defined by the procedural act because the constitution has delegated this to the nonconstitutional legislation due to which the form of cassation appeal selected in the procedural act may not be anticonstitutional. This is why I find that the adopted form of cassation appeal of the procedural act - as facultative, assigned by estimate of the instance (Supreme Cassation Court) which shall perform cassation proceeding (art. 280 of CivilProcedure Code) that it does not comply with the constitution. This is so because it contradicts to the principle of the common respect of the rules of human as well as the formed by the European Court of Human Rights principles of rights definition, efficiency when regulating the public relations, of the balance between the public and private interests. Here, due to the public interests, neglected is the private interests - the interest of the parties in the case, furthermore the constitutional delegation is towards the procedural law to establish right of cassation appeal and to define the form of the latter according to the constitutional court and in case the procedural act has delegated to Supreme Court of Cassation the authorization to establish the existence or non-existence of right of cassation appeal for the stakeholder in exchange of the unlawful appellate deed. The submission of regular cassation appeal under the new Civil-Procedure Code does not initiate permissible cassation 
proceeding which will incur specific legal consequences - the submission of regular cassation appeal before the Supreme Court of Cassation does not precondition right of cassation appeal. We shall distinct the procedural permissibility of the cassation appeal under art. 284 of Civil-Procedure Code, in relation to art. 285 and art. 286 of Civil-Procedure Code, of the permissibility of cassation proceeding under the provision of art. 280 of CivilProcedure Code, in relation to art. 288 of Civil-Procedure Code. Conducting the proceeding under art. 285 of CivilProcedure Code, the court inspects the regularity of the cassation appeal with review of the requirements of art. 284 of Civil-Procedure Code as in case of failure to remedy the irregularities by the cassation authority within one week of the announcement as well as in hypothesis of art. 286, par. 1, point 1 and point 2 of Civil-Procedure Code - in case of overdue of the cassation appeal and non-liability to appeal of the appellate resolution under ar.t 280, par. 2 of Civil-Procedure Code, the court rules for return of the cassation appeal. With the permissibility of the cassation appeal under art. 280, par. 1 of Civil-Procedure Code outlined are the conditions with which the Supreme Court of Cassation makes an estimate whether to accept appeal for review in essence and settled is proceeding on the realization as given is response to this matter. Here the court makes estimate whether to establish the existence of the right of cassation appeal of the cassation authority - right of third instance on inspection of appellate deed or to establish the inexistence of this right. The rights are established in the act and not in deed of court - the civil litigation defends the violated material law due to which is outside the competence of the Supreme Court of Cassation to make such estimate.

On the other hand the right of the party concerned for cassation appeal shall incur of the presence of appellate judgment [4], and not to be result of specific inspection made by the Supreme Court of Cassation itself where inspected is the presence of conditions foreseen in art. 280, par. 1 of Civil-Procedure Code. The right of cassation appeal incurs [5] with the ruling of the appellate judgment which right may be practiced after incurrence of the cassation appeal term. The cassation petition is submitted with the judgment is void, impermissible or inaccurate due to violation of the material act, substantial violation of the litigation rules or unjustifiable - argument from art. 281 of Civil-Procedure Code as the petition is submitted through the court having ruled the appellate judgment within one month of its handover to the parties - argument of art. 281, sentence 1 of Civil-Procedure Code. Therefore the subjective procedural right on cassation appeal is the provided and guaranteed by the court opportunity for an individual to oblige the Supreme Court of Cassation to rule on the first stage of the cassation proceeding - the proceeding on permitting the cassation appeal, estimating the statutory criteria under art. 280 of Civil-Procedure Code as result of this activity conditioned will be the obligation of the Supreme Court of Cassation as third instance on inspection of appellate deed or non-existence of this obligation.

This activity of the Supreme Court of Cassation, on the other hand, is incompatible with the functions to administer justice because it is an activity of applying the law - to apply the right in the act or not, which activity is inherent to the executive power. The discretion of the Supreme Court of Cassation in accordance with the statutory criteria - general and abstract ones, for selection of cassation appeals which are permitted to the review in essence, is related to the principle of equality of citizens, established in art. 6 of the Constitution of Republic of Bulgaria. The practiced discrimination is related to the possibility of the cassation authority to practice its right of cassation appeal which practice of right may be thwarted by the 
lack of acceptance criteria set out in art. 280 of Civil-Procedure Code. This limitation of the right of cassation appeal may be on the grounds of some of the principles, established in art. 6, par. 2 of the Constitution of Republic of Bulgaria which discrimination one.

The legislator is in his right to define the court instance, the deeds which in the legal system of Republic of Bulgaria are not liable to appeal as this does not contradict to the constitutional appeal of the state to ensure to everyone access to justice, including remedy of court mistake as the impermissibility to appeal before the cassation instance shall not be reviewed as violation of the right of the cassation defense, has accepted the constitutional court.

The prohibition of cassation appeal, defined by the judge of cassation instance - Supreme Court of Cassation through not allowing of cassation appeal of appellate deeds, violates the right of legal defense and limits the access of the party to justice. Under its authorities the legislator is entitled to define such order for inspection of the lawfulness and reasonableness of the deeds with the purpose of remedy of a mistake which will best comply with the peculiarities of one or another kind of proceeding. In the resolution the legislator shall determine criteria for permissibility of the cassation appeal, presence of which shall be inspected by the cassation instance, there is contradiction, in the basis of which is absolutizing of the right of legal defense, equalizing the right of defense and right of appeal of judgments. This is because the estimate for the availability of the permissibility criteria are not objectively clear for the estimate for their presence is given to the subjective view of a panel of Supreme Court of Cassation which behavior of the court will precondition the existence of the right of cassation appeal.

\section{Conclusion}

On the other hand criteria for appeal of court deeds may not be only the fact for possible further movement of the case, after ruling of the deed, criteria shall be the presence or lack of violated by the deed rights and/or legal interests of the parties, as a last resort also of individuals taking part in the case as well as formal criteria - for example price of the claim or subject of the case. With the so-clarified contents of the notions "right of legal defense" and "guarantee for legal defense" the legislator shall define the formal criteria - subject of the case and price of claim which shall exclude from the cassation appeal the categories cases as impermissible is exclusion of the appellate deeds of the cassation appeal as per estimate of the Supreme Court of Cassation itself, which estimate is not liable to appeal as prevented is the guarantee for legal defense - the cassation appeal. If the right of legal defense was realized in court of first and appellate instance and the law with the provisions of art. 280 of Civil-Procedure Code provide an opportunity with this resolution for arbitrariness - the right of access to court of cassation instance is only formal, not actual. On the other hand, only the legislator may exclude of cassation appeal cases but not Supreme Court of Cassation as cassation instance, as the opposite is anti-constitutional.

\section{References}

[1] In the theory maintained is the other thesis that "only the right of the party concerned for cassation appeal does not incur of the presence of appellate judgment (ruled, prepared and announced with the contents and the form in accordance with the statutory provisions - art. 235, 236 of Civil-Procedure Code). The subjective procedural right of cassation appeal is result of the specific inspection, carried out by the Supreme Court of Cassation itself, regarding the presence of special conditions, foreseen in art. 280, par. 1 
of Civil-Procedure Code. The right of cassation appeal is not precondition by the inspection under art. 288 of Civil-Procedure Code. It incurs with the positive result of its conduction and has as its source (grounds, judicial fact) the ruling of Supreme Court of Cassation, ruled in this proceeding. Prior to the ruling of Supreme Court of Cassation regarding the criteria for access to cassation appeal the right of cassation appeal is still not existing - it has not incurred or its carriers. This right is not a predicate, it is sequence of the legal activity under art. 288 of Civil-Procedure Code." See Mingova, A. "Why the judgments of Supreme Court of Cassation are not liable to appeal under art. 288 of Civil-Procedure Code" - Norm, book 5/2013, page 98-99.

[2] Author's remark. The considerations of the legislator, having conditioned the establishment of this order, according to sufficiently inconclusive are: "The possibility to restrict the access to regular third instance according to the nature of the case is reasoned with the competence of the Supreme Court of Cassation to rule interpretative resolutions on all matters as this way it will fulfill its obligation to secure the uniform application of law and development of law and on those types of cases on which it does not rule as regular third instance. The possibility to restrict the access to regular third instance according to the interest is reasoned with the fact that by ruling on cases with bigger interest, the Supreme Court of Cassation secures the uniform application of lw on all cases." See Motives to project of Civil-Procedure Code.

[3] Such as Ivanova, R., Punev, B. and Chernev, S. Comment on the new Civil-Procedure Code, Publishing house "Labor and Law", 2008, page 436

[4] In the theory maintained is the reverse statement that "the right of the party concerned itself for cassation appeal does not incur from the presence of appellate resolution (rules, compiled and announced with the contents and form according to the statutory provisions - art. 235, 236 of Civil-Procedure Code). The subjective procedural law of cassation appeal is result of specific inspection made by the Supreme Court of Cassation itself, regarding the presence of special conditions, foreseen in art. 280, par. 1 of CivilProcedure Code. The right of cassation appeal is not preconditioned by the inspection under art. 288 of Civil-Procedure Code. It is caused by the positive result of its conduction and is sourced (grounds, judicial fact) by the ruling of the Supreme Court of Cassation, ruled in this proceeding. Prior to ruling of the Supreme Court of Cassation regarding the criteria for access to cassation appeal the right of cassation appeal still does not exist - it has not incurred for its carriers. This right is not a predicate but is consequence of the judicial activity under art. 288 of Civil-Procedure Code. See Mingova, A. Why the ruling by Supreme Court of Cassation under art. 288 of CivilProcedure Code are not liable to appeal? - Norma, book 5 /2013, page 98-99.

[5] Така и Тодоров, К. „Следва ли да подлежи на обжалване определението по чл. 288 ГПК?“ - Търговско и облигационно право, кн. 6/ 2015 г., с. 59. 